\title{
Regulation of expression and activity of selenoenzymes by different forms and concentrations of selenium in primary cultured chicken hepatocytes
}

\author{
Xianshi $\mathrm{Wu}^{1,2}$, Chengwu Wei ${ }^{1}$, Cuiling Pan $^{1}$, Ying Duan ${ }^{1}$ and Kehe Huang ${ }^{1 *}$ \\ ${ }^{1}$ Institute of Nutritional and Metabolic Disorders in Domestic Animals and Fowls, Nanjing Agricultural University, College of \\ Veterinary Medicine, Nanjing 210095, People's Republic of China \\ ${ }^{2}$ College of Animal Science and Technology, Guangxi University, Nanning 530004, People's Republic of China
}

(Received 28 January 2010 - Revised 21 May 2010 - Accepted 1 June 2010 - First published online 13 July 2010)

The expression and activity of selenoenzymes are regulated by Se. In the present study, the effects of different forms and concentrations of Se on the regulation of glutathione peroxidase (GPx) activity and phospholipid hydroperoxide GPx (GPx4) and type I deiodinase (D1) mRNA levels in chicken hepatocytes were evaluated. Primary cultured chicken hepatocyte monolayers derived from male White Leghorn chickens (aged 30-40 d) were incubated for $24 \mathrm{~h}$ with 0 (control), $0 \cdot 5,1,1 \cdot 5,2,3,4$ or $5 \mu \mathrm{mol} / 1$ of Se supplied as DL-selenomethionine (Se-Met), $\kappa$-selenocarrageenan (Se-Car) or sodium selenite $\left(\mathrm{Na}_{2} \mathrm{SeO}_{3}\right)$. Compared with the control, Se significantly increased GPx activity in all the hepatocytes, but the activity was not increased in the hepatocytes treated with $5 \mu \mathrm{mol} / \mathrm{l}$ of $\mathrm{Na}_{2} \mathrm{SeO}_{3}$, with maximal effects being observed at $2 \mu \mathrm{mol} / \mathrm{l}$ of Se-Met or Se-Car and at $1.5 \mu \mathrm{mol} / 1$ of $\mathrm{Na}_{2} \mathrm{SeO}_{3}$, respectively. Significant decreases in GPx4 mRNA levels were observed in all the hepatocytes treated with Se (v. control). The D1 mRNA levels were significantly increased in all the groups treated with $\mathrm{Se}(v$. control), with maximal effects being observed at $1.5 \mu \mathrm{mol} / 1$ of Se-Met and at $0.5 \mu \mathrm{mol} / 1$ of Se-Car or $\mathrm{Na}_{2} \mathrm{SeO}_{3}$, respectively. Se-Met at doses of $1.5-5 \mu \mathrm{mol} / 1$ had a greater effect on D1 mRNA than Se-Car and $\mathrm{Na}_{2} \mathrm{SeO}_{3}$ at equivalent doses. After resulting in a maximal effect, higher Se supplementation led to a dose-dependent reduction in GPx activity and D1 mRNA levels in all the hepatocytes treated with Se. These results suggest that in chicken hepatocytes, the regulations of GPx and D1 by different forms and concentrations of Se vary.

Selenium: Glutathione peroxidase activity: Phospholipid hydroperoxide glutathione peroxidase mRNA: Type I deiodinase mRNA

$\mathrm{Se}$ is an essential trace element for animals and humans. Se deficiency is associated with numerous diseases such as Keshan disease and Kashin-Beck disease in humans ${ }^{(1,2)}$, 'white muscle disease' in calves and lambs ${ }^{(3)}$ and exudative' diathesis in chicks ${ }^{(4)}$. Supplementation of Se can enhance resistance to oxidative stress ${ }^{(5)}$, reproductive performance ${ }^{(6,7)}$ and immune function ${ }^{(8-10)}$, improve the yield and quality of meat in broilers ${ }^{(11)}$, and protect against certain types of cancers $^{(12-14)}$.

The physiological functions of Se are mediated through various selenoproteins. Se is incorporated into selenoproteins as selenocysteine $(\mathrm{Sec})$. The $\mathrm{Sec}$ residue is located at the active centre of the selenoenzymes, and is encoded by the UGA codon. The UGA codon is normally used as a translation termination codon. Incorporation of Sec into selenoproteins involves a read-through of the UGA codon. Se, a Sec incorporation sequence in the mRNA $3^{\prime}$-untranslated region, a Sec-specific transfer $\mathrm{RNA}^{\mathrm{Sec}}$ and other translational cofactors are necessary for the read-through of the UGA codon ${ }^{(15-17)}$. The status of Se affects the stability ${ }^{(18)}$ and translational efficiency of cytoplasmic mRNA of glutathione peroxidase $(\mathrm{GPx})^{(19)}$.
The family of GPx plays an important role in the protection of animals and humans against oxidative stress. Five members of the Se-dependent GPx family have been identified and sequenced in mammals ${ }^{(20)}$. In poultry, the phospholipid hydroperoxide GPx (GPx4, EC 1.11.1.12) gene has been identified and sequenced $^{(21)}$. Cellular GPx (GPx1, EC 1.11.1.9) was first identified as a Se-dependent enzyme, and it can detoxify $\mathrm{H}_{2} \mathrm{O}_{2}$ and organic peroxides to water and corresponding alcohols using GSH as the hydrogen donor ${ }^{(22)}$. GPx1 is distributed ubiquitously in various tissues. GPx4 is a membrane-associated GPx which is expressed in various tissues ${ }^{(20)}$. GPx4 can use phospholipid hydroperoxides as well as $\mathrm{H}_{2} \mathrm{O}_{2}$ and other lipid hydroperoxides as substrates ${ }^{(22)}$. Unlike that in mammalian liver, the percentage of GPx4 activity to total GPx activity in poultry liver is high $(28 \%)^{(23)}$. Type I deiodinase (D1), belonging to the Se-dependent iodothyronine deiodinase family, is found predominantly in liver, kidneys and thyroid ${ }^{(24)}$. D1 can catalyse the production of triiodothyronine from thyroxine by outer-ring deiodination. Triiodothyronine is the most bioactive form of thyroid hormone, which regulates basal metabolism, differentiation and heat production. About $80 \%$ of peripheral triiodothyronine is produced by the catalysis of D1.

Abbreviations: D1, type I deiodinase; GPx, glutathione peroxidase; GPx1, cellular GPx; GPx4, phospholipid hydroperoxide GPx; LDH, lactic dehydrogenase;

Sec, selenocysteine; Se-Car, к-selenocarrageenan; Se-Met, DL-selenomethionine.

* Corresponding author: K. Huang, fax +86 2584398669 , email khhuang@njau.edu.cn 
In rats, the mRNA levels and activities of GPx and D1 are highly correlated with the Se status ${ }^{(25)}$. Previous studies have shown that Se deficiency in the diet leads to significant decreases in the GPx3 activity and triiodothyronine concentration in plasma in chickens, and to a significant increase in thyroxine concentration in plasma ${ }^{(26,27)}$. Severe deficiency of $\mathrm{Se}$ in chickens resulted in depressions in the rate of growth and efficiency of feed utilisation ${ }^{(28)}$. Contrastingly, supplementation of Se in the diet increased the GPx activity in the plasma and tissues of turkeys, and $0.3 \mathrm{mg} \mathrm{Se} / \mathrm{kg}$ diet was required for maximal GPx activity in the plasma and liver ${ }^{(29)}$.

Supplementation of $\mathrm{Se}$ is a common practice in chicken production in China. Presently, addition of sodium selenite $\left(\mathrm{Na}_{2} \mathrm{SeO}_{3}\right)$ to the chicken diets is a prevalent method. Some researchers have suggested that the bioavailability of organic forms of $\mathrm{Se}$ (e.g. Se-enriched yeast, which contains selenomethionine (Se-Met)) is higher than that of the inorganic forms of $\mathrm{Se}$ such as $\mathrm{Na}_{2} \mathrm{SeO}_{3}{ }^{(30-32)}$. However, there are only a few studies explaining how the mechanism of organic $\mathrm{Se}$ is better than that of inorganic Se in the supplementation of Se in the chicken diet. It is known that the chicken liver is the principal organ involved in the storage and metabolism of Se, and that it can synthesise GPx1, GPx4 and D1. However, little is known about the regulation of the activity and expression of selenoenzymes in the chicken liver, which contribute to the mechanism of action of organic Se in chickens. The purposes of the present study were to evaluate the effects of different forms and concentrations of $\mathrm{Se}$ on the regulation of GPx activity and GPx4 and D1 mRNA levels in primary cultured chicken hepatocytes, and to determine the optimal doses of different forms of Se for maximal GPx activity and maximal GPx4 and D1 mRNA levels in vitro.

\section{Materials and methods}

The experimental use of animals and procedures followed were approved by the Nanjing Agricultural University Animal Care Committee.

\section{Isolation and culture of hepatocytes}

Male White Leghorn chickens (aged 30-40d) were used to obtain hepatocytes. Isolation of hepatocytes was performed using the collagenase perfusion method as described previously ${ }^{(33)}$, with some modifications. Isolated cells were dispersed in $60 \mathrm{ml}$ of serum-free L-15 medium (Invitrogen, Carlsbad, CA, USA) supplemented with $0.2 \%$ (w/v) bovine serum albumin and antibiotics $(100 \mathrm{IU} / \mathrm{ml}$ penicillin, $100 \mu \mathrm{g} / \mathrm{ml}$ streptomycin and $0.25 \mu \mathrm{g} / \mathrm{ml}$ amphotericin B) at $4^{\circ} \mathrm{C}$. Purification of hepatocytes was performed according to the method described by Wu et al. ${ }^{(34)}$. The viability of the isolated hepatocytes was 92.3 (SD 1.4) \% (n 3), which was determined by the $0.4 \%$ trypan blue dye exclusion method, and the cell yield from each liver preparation was $4.1($ SD 0.82$) \times 10^{8}$ hepatocytes (n 3). Evaluation of the cells done using light microscopy indicated that about $95 \%$ of the collected cells were hepatocytes.

Culturing of hepatocytes was performed according to the method described by Fujii et al. ${ }^{(33)}$, with some modifications. Hepatocytes were seeded into six-well plates at a density of $2 \times 10^{6}$ viable cells per well in $2 \mathrm{ml}$ of L-15 medium (supplemented with $5 \%$ fetal bovine serum, 33 mm-HEPES, $2 \mathrm{mM}$-L-glutamine, $0.2 \%(\mathrm{w} / \mathrm{v})$ bovine serum albumin, $100 \mathrm{nM}$-dexamethasone, $5 \mathrm{mg} / \mathrm{l}$ transferrin, $1 \mu \mathrm{mol} / 1$ insulin and antibiotics, $\mathrm{pH} 7 \cdot 65$ ). Cells were cultured at $37^{\circ} \mathrm{C}$ in a humidified atmosphere. After a plating period of $4 \mathrm{~h}$, cell monolayers were washed twice with Hanks' balanced salt solution, and $3 \mathrm{ml}$ of fresh serum-free L-15 medium were added to each well. Thereafter, the medium was substituted with serum-free L-15 medium every $24 \mathrm{~h}$.

\section{Cell treatments}

At $48 \mathrm{~h}$ after seeding, the culture medium was removed, and hepatocyte monolayers were washed three times with Hanks' balanced salt solution. Then, hepatocytes were grown in $3 \mathrm{ml}$ of fresh serum-free L-15 medium, and were treated with 0 (control) $0 \cdot 5,1,1 \cdot 5,2,3,4$ or $5 \mu \mathrm{mol} / 1$ of Se supplied as DL-Se-Met (Sigma, St Louis, MO, USA), к-selenocarrageenan (Se-Car, The First Institute of Oceanography, Qingdao, China) or $\mathrm{Na}_{2} \mathrm{SeO}_{3}$ (Sigma). Following incubation for $24 \mathrm{~h}$, the culture medium was collected into $2 \mathrm{ml}$ Eppendorf tubes for assay of lactic dehydrogenase $(\mathrm{LDH})$, and the cells were harvested for the analysis of enzyme activity and mRNA. Each treatment was done in six wells (three wells were used for the measurement of GPx activity, and the other wells were used for mRNA analysis) in three separate experiments.

\section{Preparation of hepatocyte lysates}

After $24 \mathrm{~h}$ of incubation with different forms and concentrations of $\mathrm{Se}$, hepatocyte monolayers were washed three times with ice-cold $\mathrm{Ca}^{2+} / \mathrm{Mg}^{2+}$-free PBS, and were harvested by scraping into $1 \mathrm{ml}$ of cold Tris buffer $(20 \mathrm{~mm}$-Tris-HCl, $\mathrm{pH} 7 \cdot 5,2$ mm-EDTA and $0 \cdot 1 \%$ peroxide-free Triton X-100). Hepatocyte lysates were then prepared by ultrasonication for $30 \mathrm{~s}$ in ice-cold water, and centrifuged at $12000 \mathrm{~g}$ for $15 \mathrm{~min}$ at $4{ }^{\circ} \mathrm{C}$. The supernatants were aliquoted and stored at $-20^{\circ} \mathrm{C}$ for the subsequent analysis of GPx activity.

\section{Analytical methods}

Measurement of protein concentration of hepatocyte lysates. Total protein concentration was measured using a Bradford Protein Assay Kit (Beyotime Institute of Biotechnology, Jiangsu, China). The results obtained for GPx activity were corrected for total protein concentration.

Measurement of lactic dehydrogenase activity in the incubation medium. Hepatocyte toxicity was analysed by measuring the LDH activity in the incubation medium. The culture medium was collected into $2 \mathrm{ml}$ Eppendorf tubes at the end of the incubation, and was centrifuged at $12000 \mathrm{~g}$ for $15 \mathrm{~min}$ at $4^{\circ} \mathrm{C}$. The supernatants were stored at $-20^{\circ} \mathrm{C}$ until analysis (within $3 \mathrm{~d}$ ). The measurement of $\mathrm{LDH}$ activity in the incubation medium was performed as described previously ${ }^{(35)}$. One unit of enzyme activity was defined as $1 \mu \mathrm{mol}$ of reduced nicotinamide adenine dinucleotide oxidised per min. The $\mathrm{LDH}$ activity in the culture medium was expressed as units per litre. All the samples were measured in duplicate.

Measurement of glutathione peroxidase activity in hepatocyte cytosol. The GPx activity in hepatocyte cytosol was 
measured according to the method described by Lei et al. ${ }^{(36)}$, using tert-butyl hydroperoxide as the peroxide substrate. Briefly, $50 \mu \mathrm{l}$ of hepatocyte lysate were transferred into a $3 \mathrm{ml}$ quartz cuvette containing $1900 \mu \mathrm{l}$ of the reaction mixture (50 mM-Tris- $\mathrm{HCl}, \mathrm{pH} 7 \cdot 5,2$ mM-EDTA, $0 \cdot 1 \mathrm{~mm}-\mathrm{NADPH}$, $2 \mathrm{~mm}-\mathrm{GSH}, 1 \mathrm{mM}^{-\mathrm{NaN}_{3}}$ and $0.9 \mathrm{IU}$ of glutathione reductase (Sigma)). The reaction mixture was preincubated for $3 \mathrm{~min}$ at $25^{\circ} \mathrm{C}$, and the reaction was initiated by adding $50 \mu$ l of tertbutyl hydroperoxide $(8 \mathrm{~mm})$. The rate of oxidation of NADPH was monitored using a spectrophotometer at $340 \mathrm{~nm}$ for $5 \mathrm{~min}$ at $25^{\circ} \mathrm{C}$. The non-enzymatic reaction rate was determined by substituting water (serving as the blank) with the hepatocyte lysate, and by recording the decrease in NADPH absorbance. One unit of enzyme activity was defined as $1 \mu \mathrm{mol}$ of NADPH oxidised per min under these conditions. The GPX activity in hepatocyte cytosol was expressed as $\mathrm{mU} / \mathrm{mg}$ of total cell protein. All the samples were measured in duplicate.

Measurement of phospholipid hydroperoxide glutathione peroxidase and type I deiodinase $m R N A$ levels by quantitative $R T-P C R$. After $24 \mathrm{~h}$ of incubation with different forms and concentrations of $\mathrm{Se}$, the medium was removed, and the cell monolayers were washed three times with ice-cold $\mathrm{Ca}^{2+}$ / $\mathrm{Mg}^{2+}$-free PBS. Total RNA was isolated from the hepatocyte monolayers using the TRIzol reagent (Invitrogen) according to the manufacturer's protocol. The dried RNA pellets were resuspended in $40 \mu$ l of diethyl pyrocarbonate-treated water. The concentration and purity of the total RNA were determined spectrophotometrically at $260 / 280 \mathrm{~nm}$. The total RNA was immediately used or stored at $-70^{\circ} \mathrm{C}$ before complementary DNA synthesis.

First-strand complementary DNA was synthesised from $2 \mu \mathrm{g}$ of total RNA using Oligo-dT primers and SuperScript II RT (Invitrogen) according to the manufacturer's instructions. Synthesised complementary DNA was diluted ten times with sterile water, and stored at $-20^{\circ} \mathrm{C}$ before use.

Primer Premier software (PREMIER Biosoft International, Palo Alto, CA, USA) was used to design specific primers for $\beta$-actin, GPX4 and D1 based on known chicken sequences (Table 1). Quantitative real-time PCR were performed on an ABI PRISM 7300 Detection System (Applied Biosystems, Foster City, CA, USA) according to the method described by $\mathrm{Wu}$ et al. ${ }^{(34)}$, with some modifications. The PCR procedure for $\beta$-actin, GPx4 and D1 consisted of a step performed at $95^{\circ} \mathrm{C}$ for $2 \mathrm{~min}$ followed by forty cycles at $95^{\circ} \mathrm{C}$ for $15 \mathrm{~s}$, $58^{\circ} \mathrm{C}$ for $15 \mathrm{~s}$ and $72^{\circ} \mathrm{C}$ for $30 \mathrm{~s}$. The melting curve analysis showed only one peak for each PCR product. Electrophoresis was performed with the PCR products to verify primer specificity and purity of the products. The calculation of the number of copies of each sample was performed from the respective standard curve using the 7300 system software. The ratio of mRNA levels of GPx4 and D1 to that of $\beta$-actin internal control was used for statistical comparison of the different treatments.

\section{Statistical analysis}

Statistical analysis of the LDH and GPx activities and GPx4 and D1 mRNA levels was performed using the SPSS 11.5 for Windows statistical software package (SPSS, Inc., Cary, NC, USA). When a significant value $(P<0.05)$ was obtained using one-way ANOVA, further analysis was done. All the data showed a normal distribution and passed equal variance testing. Differences between means were assessed by Tukey's honestly significant difference test of post hoc multiple comparisons. Data were expressed as means and standard deviations. Differences were considered as significant at $P<0 \cdot 05$.

\section{Results}

Effect of selenium supplementation on lactic dehydrogenase release

The effects of different forms and concentrations of Se on the release of $\mathrm{LDH}$ into the culture medium are shown in Fig. 1. Compared with the control, Se-Met at doses of $1-3 \mu \mathrm{mol} / \mathrm{l}$ $(P<0.05)$ significantly lowered LDH release in the hepatocytes after incubation for $24 \mathrm{~h}$, but at doses of $0.5,4$ or $5 \mu \mathrm{mol} / \mathrm{l}(P>0.05)$, it did not lower the LDH release. In the hepatocytes incubated with Se-Car, significantly higher LDH release was observed at doses of 3,4 or $5 \mu \mathrm{mol} / 1(P<0.05$, $v$. control). The release of $\mathrm{LDH}$ was significantly increased in the hepatocytes treated with $2,3,4$ or $5 \mu \mathrm{mol} / 1$ of $\mathrm{Na}_{2} \mathrm{SeO}_{3}(P<0 \cdot 05, v$. control $)$. The response occurred in a dose-dependent manner. The release of $\mathrm{LDH}$ induced by $\mathrm{Na}_{2} \mathrm{SeO}_{3}$ at doses of $2,3,4$ or $5 \mu \mathrm{mol} / 1$ was significantly higher than that induced by Se-Met and Se-Car at equivalent doses, respectively. Furthermore, the release of $\mathrm{LDH}$ induced by Se-Car at doses of 3, 4 or $5 \mu \mathrm{mol} / 1$ was significantly higher than that induced by Se-Met at equivalent doses. Cell detachments were not observed during light microscopy in the hepatocytes incubated with $\mathrm{Na}_{2} \mathrm{SeO}_{3}$ at a dose of $5 \mu \mathrm{mol} / \mathrm{l}$.

Effect of selenium supplementation on glutathione peroxidase activity

The effects of different forms and concentrations of Se on the GPx activity are shown in Fig. 2. Compared with the control,

Table 1. Primers used for quantitative real-time PCR

\begin{tabular}{|c|c|c|c|c|}
\hline Primers & Nucleotide sequence $\left(5^{\prime}-3^{\prime}\right)$ & Target gene & GenBank accession no. & PCR fragment length (bp) \\
\hline $\begin{array}{l}\beta-\text { Actin-F (forward) } \\
\beta-\text { Actin-R (reverse) }\end{array}$ & $\begin{array}{l}\text { tca cca cca cag ccg aga ga } \\
\text { cga aat cca gtg cga cgt agc }\end{array}$ & $\beta$-Actin & NM_205518 & 72 \\
\hline $\begin{array}{l}\text { GPx4-F (forward) } \\
\text { GPx4-R (reverse) }\end{array}$ & $\begin{array}{l}\text { cat cac caa cgt ggc gtc caa } \\
\text { gca gcc cct tct cag cgt atc }\end{array}$ & GPx4 & AF498316 & 92 \\
\hline $\begin{array}{l}\text { D1-F (forward) } \\
\text { D1-R (reverse) }\end{array}$ & $\begin{array}{l}\text { cgc tat acc aca ggc agt aat g } \\
\text { agt tta tcc tgc acc gta ttc } t\end{array}$ & D1 & Y11110 & 101 \\
\hline
\end{tabular}

GPx4, phospholipid hydroperoxide glutathione peroxidase; D1, type I deiodinase. 


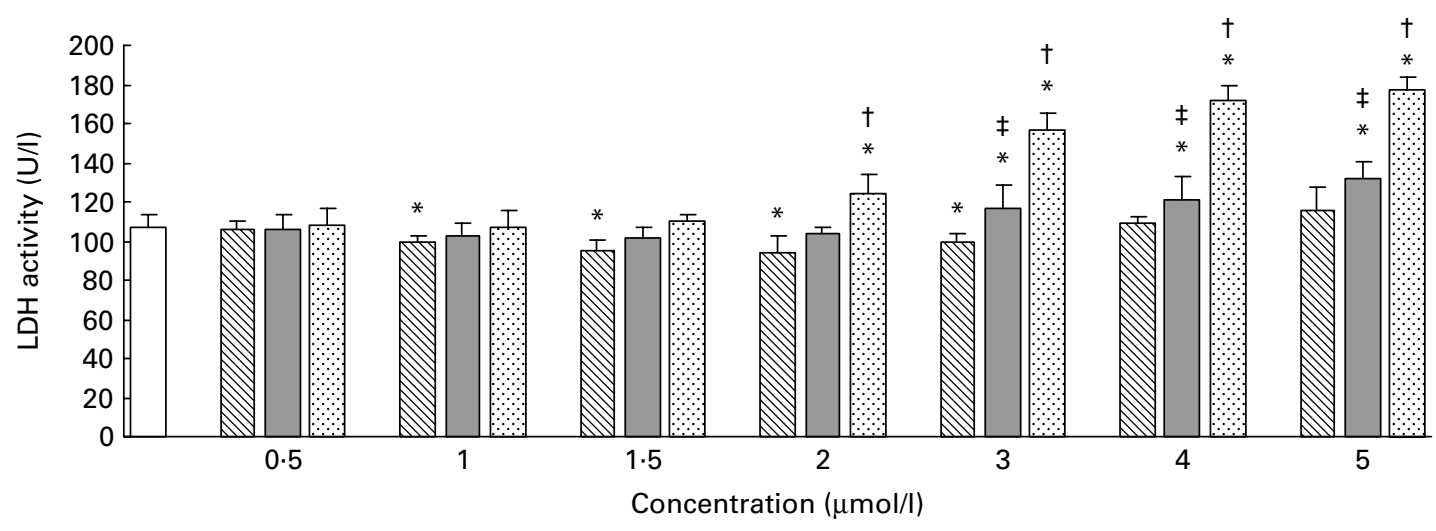

Fig. 1. Effects of different forms and concentrations of Se on lactic dehydrogenase (LDH) release from hepatocytes. The primary cultured chicken hepatocyte monolayers were incubated with 0 (control), $0.5,1,1.5,2,3,4$ or $5 \mu \mathrm{mol} / \mathrm{l}$ of Se supplied as DL-selenomethionine (Se-Met), $\mathrm{k}$-selenocarrageenan (Se-Car) or sodium selenite $\left(\mathrm{Na}_{2} \mathrm{SeO}_{3}\right)$ for $24 \mathrm{~h}$. The $\mathrm{LDH}$ activity in the culture medium was used to evaluate the integrity of cell membrane. Bars represent means and standard deviations of triplicate culture media. *Mean values were significantly different from the control assessed by one-way ANOVA and then by Tukey's multiple comparison test $(P<0.05)$. † Mean values were significantly different from Se-Met groups and Se-Car groups at equivalent doses $(P<0.05)$. $¥$ Mean values were significantly different from Se-Met groups at equivalent doses $(P<0.05)$. $\square$, Control; $\mathbb{\mathbb { N }}$, Se-Met; $\square$, Se-Car; $\square, \mathrm{Na}_{2} \mathrm{SeO}_{3}$.

Se-Met or Se-Car at doses of $0 \cdot 5-5 \mu \mathrm{mol} / 1$ and $\mathrm{Na}_{2} \mathrm{SeO}_{3}$ at doses of $0.5-4 \mu \mathrm{mol} / \mathrm{l}$ significantly increased the GPx activity in the hepatocytes, but $\mathrm{Na}_{2} \mathrm{SeO}_{3}$ at a dose of $5 \mu \mathrm{mol} / \mathrm{l} \mathrm{did}$ not increase the GPx activity $(P<0 \cdot 05)$. In the hepatocytes treated with Se-Met or Se-Car, a significant dose-dependent increase in GPx activity was observed ( $v$. control), up to a maximum at a dose of $2 \mu \mathrm{mol} / \mathrm{l}$. For $\mathrm{Na}_{2} \mathrm{SeO}_{3}$ supplementation, $1.5 \mu \mathrm{mol} / \mathrm{l}$ was found to be the most effective dose. After resulting in a maximal GPx activity, higher Se supplementation led to a dose-dependent reduction in GPx activity in all the groups treated with Se. The increases in GPx activity induced by Se-Met at doses of $0 \cdot 5,1,2,3$ or $5 \mu \mathrm{mol} / 1$ were significantly higher than those induced by $\mathrm{Se}-\mathrm{Car}$ and $\mathrm{Na}_{2} \mathrm{SeO}_{3}$ at equivalent doses $(P<0.05)$, respectively. At $1.5 \mu \mathrm{mol} / \mathrm{l}$ of added $\mathrm{Se}, \mathrm{Na}_{2} \mathrm{SeO}_{3}$ had a relatively greater effect on GPx activity than Se-Car $(P<0.05)$, but the effect was not greater than that of Se-Met. However, Se-Car at doses of $2,3,4$ or $5 \mu \mathrm{mol} / 1$ had a relatively greater effect on GPx activity than $\mathrm{Na}_{2} \mathrm{SeO}_{3}$ at equivalent doses $(P<0 \cdot 05)$. Moreover, $2 \mu \mathrm{mol} / \mathrm{l}$ of $\mathrm{Se}$ from Se-Met resulted in the highest GPx activity in all the groups treated with Se.

\section{Effect of selenium supplementation on phospholipid hydroperoxide glutathione peroxidase mRNA levels}

The GPx4 mRNA levels measured by quantitative RT-PCR are shown in Fig. 3. Compared with the control, Se-Met, Se-Car or $\mathrm{Na}_{2} \mathrm{SeO}_{3}$ significantly decreased GPx4 mRNA levels in a dose-dependent manner in all the groups $(P<0.05)$. At $0.5-1.5 \mu \mathrm{mol} / 1$ of added Se, the GPx4 mRNA levels were not significantly different between the groups treated with Se-Met, Se-Car or $\mathrm{Na}_{2} \mathrm{SeO}_{3}(P>0.05)$. The GPx4 mRNA levels in the hepatocytes treated with Se-Met at doses of $2-5 \mu \mathrm{mol} / \mathrm{l}$ were higher than those in the hepatocytes treated with $\mathrm{Se}-\mathrm{Car}$ or $\mathrm{Na}_{2} \mathrm{SeO}_{3}$ at equivalent doses.

\section{Effect of selenium supplementation on type I deiodinase mRNA levels}

The D1 mRNA levels measured by quantitative RT-PCR are shown in Fig. 4. Compared with the control, Se-Met, Se-Car or $\mathrm{Na}_{2} \mathrm{SeO}_{3}$ significantly increased the D1 mRNA levels in all the groups $(P<0.05)$. The maximal D1 mRNA levels

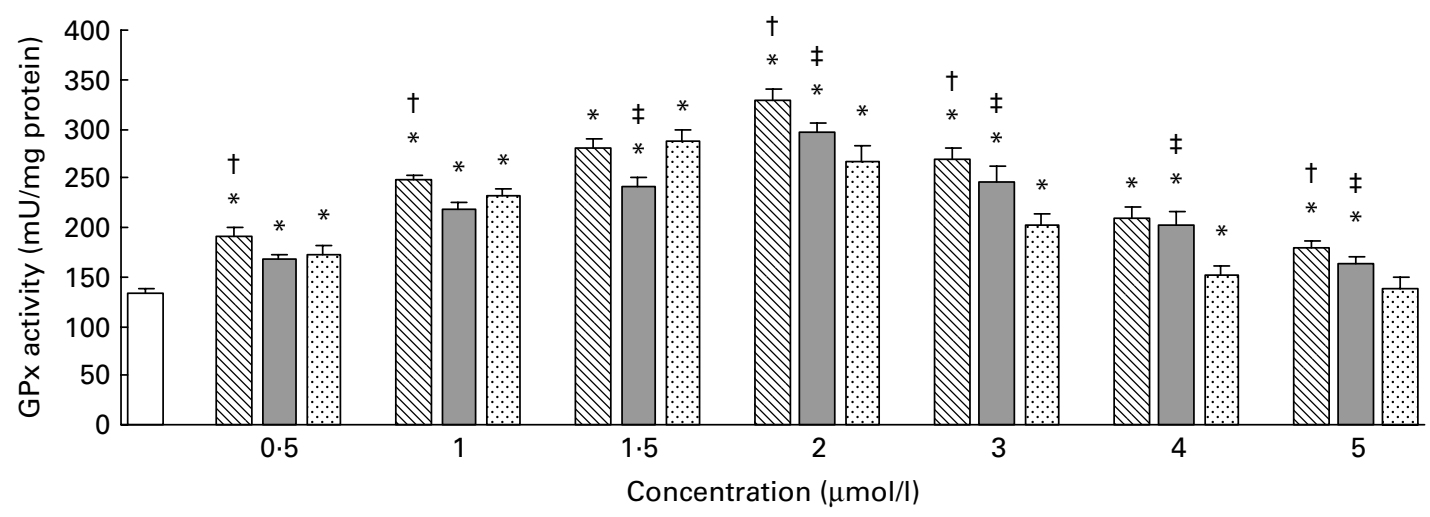

Fig. 2. Effects of different forms and concentrations of Se on glutathione peroxidase (GPx) activity in chicken hepatocytes. The primary cultured chicken hepatocyte monolayers were treated with 0 (control), $0.5,1,1.5,2,3,4$ or $5 \mu \mathrm{mol} / \mathrm{l}$ of Se supplied as DL-selenomethionine (Se-Met), $\kappa$-selenocarrageenan (Se-Car) or sodium selenite $\left(\mathrm{Na}_{2} \mathrm{SeO}_{3}\right)$ for $24 \mathrm{~h}$. The GPx activity in hepatocyte cytosol was measured using a spectrophotometric method, and expressed as mU/mg protein. Bars represent means and standard deviations of triplicate cultures. * Mean values were significantly different from the control assessed by one-way ANOVA and then by Tukey's multiple comparison test $(P<0.05)$. † Mean values were significantly different from $\mathrm{Se}-\mathrm{Car}$ groups and $\mathrm{Na}_{2} \mathrm{SeO} \mathrm{O}_{3}$ groups at equivalent doses $(P<0.05)$. $\ddagger$ Mean values were significantly different from $\mathrm{Na}_{2} \mathrm{SeO}_{3}$ groups at equivalent doses $(P<0.05)$. $\square, \mathrm{Control} ; \mathbb{\mathbb { N }}, \mathrm{Se}-\mathrm{Met} ; \square, \mathrm{Se}-\mathrm{Car} ; \mathrm{⿴囗十}, \mathrm{Na} \mathrm{SeO}_{3}$. 


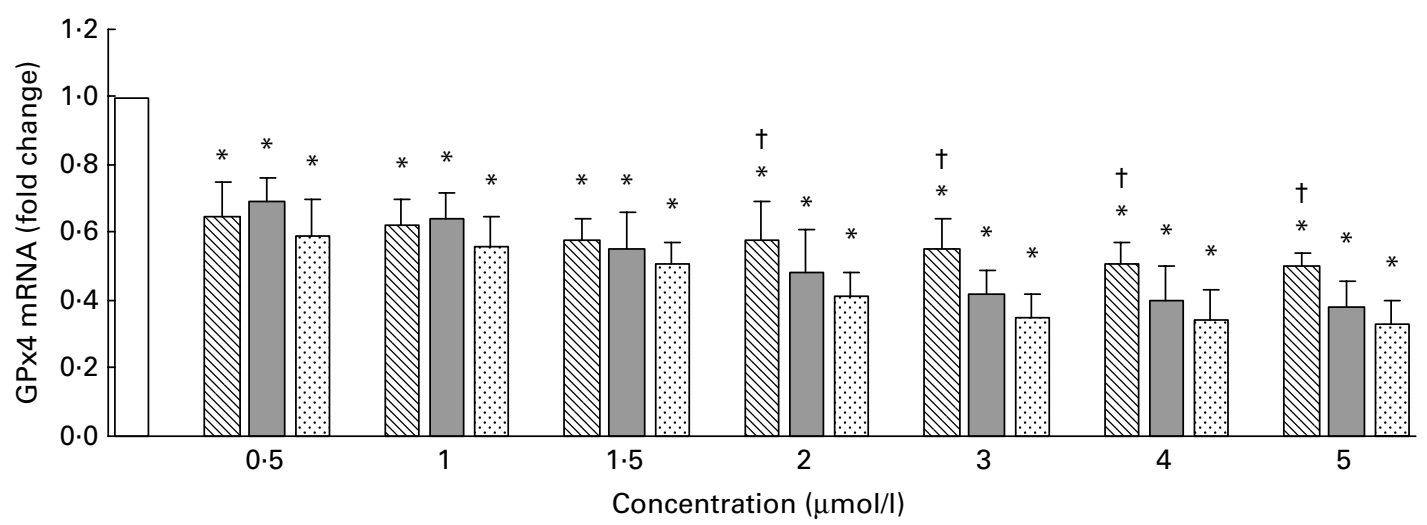

Fig. 3. Effects of different forms and concentrations of Se on phospholipid hydroperoxide glutathione peroxidase (GPx4) mRNA of chicken hepatocytes. The primary cultured chicken hepatocyte monolayers were treated with 0 (control), 0.5, 1, 1.5, 2, 3, 4 or $5 \mu \mathrm{mol} / \mathrm{l}$ of Se supplied as DL-selenomethionine (Se-Met), $\kappa$-selenocarrageenan (Se-Car) or sodium selenite $\left(\mathrm{Na}_{2} \mathrm{SeO}_{3}\right)$ for $24 \mathrm{~h}$. GPx4 mRNA of chicken hepatocytes was measured by quantitative real-time RT-PCR, and the ratio of mRNA level of GPx4 to that of $\beta$-actin internal control was used for statistical comparison. Bars represent means and standard deviations of triplicate cultures. * Mean values were significantly different from the control assessed by one-way ANOVA and then by Tukey's multiple comparison test $(P<0.05)$. $†$ Mean

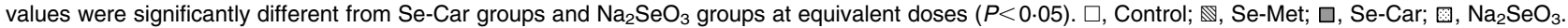

were observed in the hepatocytes treated with $1.5 \mu \mathrm{mol} / 1$ of Se-Met and $0.5 \mu \mathrm{mol} / 1$ of Se-Car or $\mathrm{Na}_{2} \mathrm{SeO}_{3}$ (v. control). After resulting in a maximal D1 mRNA level, higher Se supplementation led to a dose-dependent reduction in D1 mRNA levels in all the groups treated with Se. The degree of reduction in D1 mRNA levels was relatively small in the groups treated with Se-Met than in the groups treated with $\mathrm{Se}-\mathrm{Car}$ or $\mathrm{Na}_{2} \mathrm{SeO}_{3}$. At $0.5 \mu \mathrm{mol} / \mathrm{l}$ of added $\mathrm{Se}, \mathrm{Se}-\mathrm{Car}$ and $\mathrm{Na}_{2} \mathrm{SeO}_{3}$ had a relatively greater effect on D1 mRNA than Se-Met $(P<0.05)$. There were no differences between the hepatocytes treated with $\mathrm{Se}-\mathrm{Met}, \mathrm{Se}-\mathrm{Car}$ and $\mathrm{Na}_{2} \mathrm{SeO}_{3}$ at a dose of $1 \mu \mathrm{mol} / 1$. At $1 \cdot 5-5 \mu \mathrm{mol} / \mathrm{l}$ of added Se, however, Se-Met had a relatively greater effect on D1 mRNA than Se-Car and $\mathrm{Na}_{2} \mathrm{SeO}_{3}(P<0 \cdot 05)$. Moreover, Se-Car at doses of 4 or $5 \mu \mathrm{mol} / 1$ had a relatively greater effect on D1 mRNA than $\mathrm{Na}_{2} \mathrm{SeO}_{3}$ at equivalent doses $(P<0.05)$.

\section{Discussion}

The population doubling time of the chicken hepatocytes during the logarithmic phase of growth was $46 \mathrm{~h}$ when they were cultured in the serum-free L-15 medium (data not shown).

The compounds of Se are generally classified into inorganic and organic forms. The primary metabolic pathway of Se in animals and cells is the reduction of the elemental form followed by methylation, producing methylselenol, dimethylselenide and trimethylselenonium cation ${ }^{(37,38)}$, which are excreted through lungs or kidneys. Selenide plays an intermediary role in the process of Se metabolism, and is either used for selenoprotein synthesis or used for methylation ${ }^{(38)}$. There are some differences in the metabolism of inorganic and organic forms of Se. Inorganic forms of $\mathrm{Se}$ (e.g. $\mathrm{Na}_{2} \mathrm{SeO}_{3}$ ) are reduced

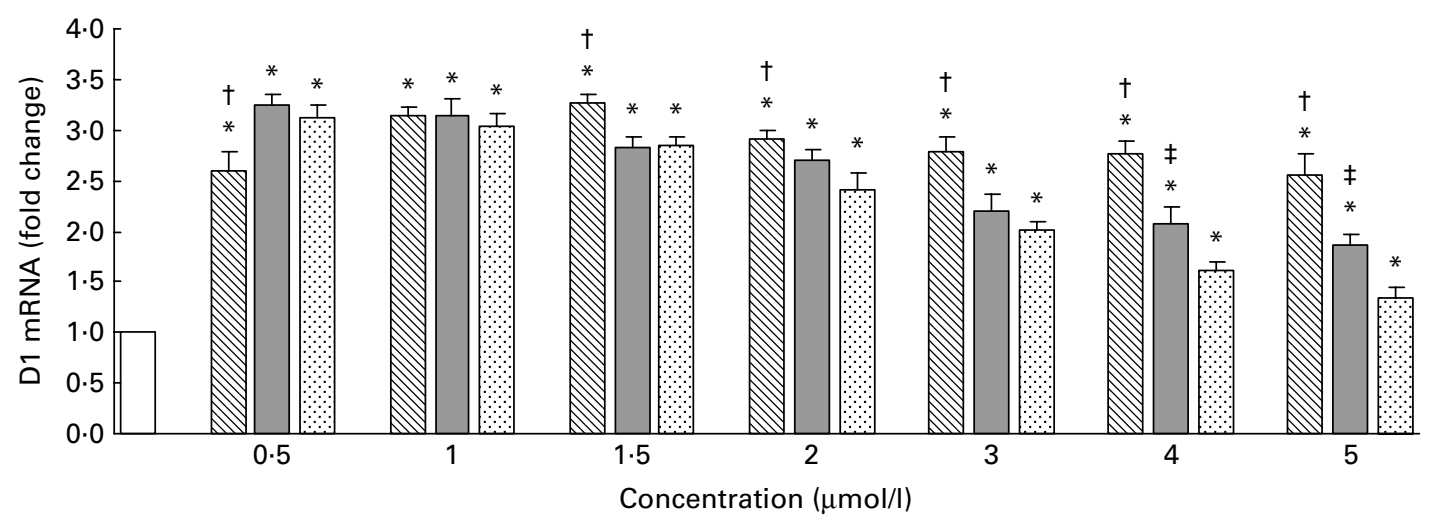

Fig. 4. Effects of different forms and concentrations of Se on type I deiodinase (D1) mRNA of chicken hepatocytes. The primary cultured chicken hepatocyte monolayers were treated with 0 (control), 0.5, 1, 1.5, 2, 3, 4 or $5 \mu \mathrm{mol} / \mathrm{l}$ of Se supplied as DL-selenomethionine (Se-Met), $\kappa-$ selenocarrageenan (Se-Car) or sodium selenite $\left(\mathrm{Na}_{2} \mathrm{SeO}_{3}\right)$ for $24 \mathrm{~h}$. D1 mRNA of chicken hepatocytes was measured by quantitative real-time RT-PCR, and the ratio of mRNA level of D1 to that of $\beta$-actin internal control was used for statistical comparison. Bars represent means and standard deviations of triplicate cultures. ${ }^{*}$ Mean values were significantly different from the control assessed by one-way ANOVA and then by Tukey's multiple comparison test $(P<0.05)$. $†$ Mean values were significantly different from Se-Car groups and $\mathrm{Na}_{2} \mathrm{SeO}_{3}$ groups at equivalent doses $(P<0.05)$. $¥$ Mean values were significantly different from $\mathrm{Na}_{2} \mathrm{SeO}$ groups at equivalent doses $(P<0.05)$. $\square$, Control; $\mathbb{8}$, Se-Met; $\square, \mathrm{Se}-\mathrm{Car} ; \mathrm{O}, \mathrm{Na}_{2} \mathrm{SeO}_{3}$ 
to the selenide state using reducing equivalents from GSH and NADPH. Organic forms of Se (e.g. Se-Met) release Se in the selenide state as a result of catabolism. Moreover, Se-Met can be incorporated non-specifically into proteins as a substitute for sulphur-containing methionine. Greater tissue retention of organic Se than of inorganic Se from $\mathrm{Na}_{2} \mathrm{SeO}_{3}$ from Seenriched yeast was observed in broilers ${ }^{(32,39)}$ and swines ${ }^{(40)}$. The distribution of Se in different organs of laying hens fed Se-supplemented diets varied, and the liver was found to be the principal organ involved in the storage of $\mathrm{Se}^{(41)}$. The results of the present study showed that the regulations of the GPx activity and GPx4 and D1 mRNA levels by different forms of Se varied in primary cultured chicken hepatocytes. This may, in part, be caused by the metabolic differences of these forms of Se in the cultured cells.

Previous studies have suggested that organic forms of Se (e.g. Se-Met) are less toxic than inorganic forms of Se such as $\mathrm{Na}_{2} \mathrm{SeO}_{3}^{(42,43)}$. LDH is a stable cytosolic enzyme, which becomes extracellular when the cell membrane is damaged. Therefore, the hepatocyte toxicity of the different forms of Se used in the present study can be analysed by measuring the LDH activity in the culture supernatant. The results of the present study are similar to those of our previous report ${ }^{(34)}$, and suggest that Se-Met is less toxic than $\mathrm{Na}_{2} \mathrm{SeO}_{3}$ and Se-Car, and that Se-Car is slightly less toxic than $\mathrm{Na}_{2} \mathrm{SeO}_{3}$. Earlier research has shown that incubation of isolated rat hepatocytes for $2 \mathrm{~h}$ with $\mathrm{Se}$ supplied as $\mathrm{Na}_{2} \mathrm{SeO}_{3}$ at concentrations higher than $6 \cdot 3 \mu \mathrm{mol} / 1$ led to a decrease in cell viability compared with the controls ${ }^{(44)}$. Cytotoxicity was not observed in the primary cultured rabbit hepatocytes treated with $\mathrm{Na}_{2} \mathrm{SeO}_{3}$ at a dose of $100 \mathrm{ng} / \mathrm{ml}$ (about $1.27 \mu \mathrm{mol} / \mathrm{l})^{(45)}$. The results of the present study were similar to these findings.

Recent research has shown that supplementation with $\mathrm{Se}$ supplied as $\mathrm{Na}_{2} \mathrm{SeO}_{3}$ led to a significant increase in GPx activity in growing male turkey livers, and that $0.3 \mathrm{mg} \mathrm{Se} / \mathrm{kg}$ diet was required for the maximal GPx activity in the liver ${ }^{(29)}$. Lei et al. ${ }^{(46)}$ also reported that Se supplementation at a dose of $0.2 \mathrm{mg} / \mathrm{kg}$ diet was required to support the full expression of GPx1 in pig livers. The results of the study done by Salman et al. ${ }^{(47)}$ indicated that the supplementation of organic Se to the diets containing adequate Se increased GPx activity in broiler livers and other tissues. In the present study, significant increases in GPx activity were observed in all the hepatocytes treated with Se except in the hepatocytes treated with $5 \mu \mathrm{mol} / 1$ of $\mathrm{Na}_{2} \mathrm{SeO}_{3}$. These results are similar to those of our previous research ${ }^{(34)}$. After resulting in a maximal effect, higher Se supplementation led to a dose-dependent decreasing trend of GPx activity in all the hepatocytes treated with Se. We believe that the decreases in GPx activity are related to the excess supplementation and cytotoxicity of Se. Toxicity associated with Se leads to the inhibition of cell growth $^{(48)}$, DNA fragmentation ${ }^{(49)}$ and reduction in protein synthesis $^{(50)}$. Ebert et al. ${ }^{(51)}$ reported that GPx1 activity was enhanced by 1.8 -fold in the bone marrow stromal cells cultured in the presence of $100 \mathrm{~nm}$ Se supplied as $\mathrm{Na}_{2} \mathrm{SeO}_{3}$. Supplementation of $\mathrm{Se}$ as $\mathrm{Na}_{2} \mathrm{SeO}_{3}(1 \mu \mathrm{mol} / \mathrm{l})$ led to significant increases in GPx1 activity in mouse hepatoma cells (about 2-fold), and then GPx1 activity exhibited a decreasing trend at a dose of $2 \mu \mathrm{mol} / \mathrm{l}^{(52)}$. In the present study, the increases in GPx activity induced by Se-Met at doses of 0.5 , $1,2,3$ or $5 \mu \mathrm{mol} / 1$ were significantly higher than those induced by Se-Car and $\mathrm{Na}_{2} \mathrm{SeO}_{3}$ at equivalent doses $(P<0.05)$. Se-Car at doses of $2,3,4$ or $5 \mu \mathrm{mol} / 1$ had a relatively greater effect on GPx activity than $\mathrm{Na}_{2} \mathrm{SeO}_{3}$ at equivalent doses $(P<0 \cdot 05)$. These results are similar to those of our previous report $^{(34)}$, and suggest that different forms and concentrations of Se have varied effects on the regulation of the GPx activity in primary cultured chicken hepatocytes.

Sneddon et al. ${ }^{(53)}$ reported that $\mathrm{Se}$ supplied as $\mathrm{Na}_{2} \mathrm{SeO}_{3}$ at a dose of $0.114 \mu \mathrm{mol} / 1$ led to an optimal GPx4 mRNA level in human umbilical vein endothelial cells. In HPL1D cells from human lung peripheral epithelium, a maximal GPx4 mRNA level was observed at $0 \cdot 1 \mu \mathrm{mol} / \mathrm{l}$ of added Se supplied as $\mathrm{Na}_{2} \mathrm{SeO}_{3}{ }^{(54)}$. Because the mRNA sequences of GPx1 gene of poultry are not available in the GenBank and the primers of GPx1 cannot be designed, GPx1 mRNA levels in the cultured cells cannot be measured by quantitative RT-PCR. In the present study, significant decreases in GPx4 mRNA levels were observed in all the hepatocytes treated with Se-Met, Se-Car or $\mathrm{Na}_{2} \mathrm{SeO}_{3}$ compared with those treated with the control $(P<0.05)$. These results suggest that the concentration of Se required for the maximal expression of GPX 4 mRNA in the primary cultured chicken hepatocytes is relatively low, despite the different forms of Se (speculated $<0.5 \mu \mathrm{mol} / \mathrm{l}$ ). Using in vivo experiments, it was found that Se requirement needed to reach the plateau level of GPx4 mRNA in rat livers was about at $0.033 \mathrm{mg} / \mathrm{kg} \mathrm{diet}{ }^{(36)}$. In addition, some researchers believed that Se deficiency had no effect on the expression of GPx4 mRNA in rat livers ${ }^{(19,25,55)}$.

Supplementation of Se as $\mathrm{Na}_{2} \mathrm{SeO}_{3}(0 \cdot 1 \mathrm{mg} / \mathrm{kg}$ diet $)$ led to significant increases in the mRNA level and activity of D1 in rat livers, but Se supplementation above a nutritionally adequate level $\left(2 \mathrm{mg} / \mathrm{kg}\right.$ diet) reduced the enzyme activity ${ }^{(56)}$. The results of the study done by Bermano et al. ${ }^{(25)}$ showed that mRNA level and activity of D1 in rat livers required $0 \cdot 104 \mathrm{mg} \mathrm{Se} / \mathrm{kg}$ diet to reach plateau levels. However, Sunde et $a{ }^{(55)}$ reported that dietary Se requirement needed to reach the plateau levels of D1 mRNA in the livers of pregnant and lactating rats was less than $0.01 \mathrm{mg} / \mathrm{kg}$ diet. In the present study, the maximal D1 mRNA levels were observed in the primary cultured chicken hepatocytes treated with $1.5 \mu \mathrm{mol} / \mathrm{l}$ of Se-Met (about 3.26-fold $v$. control) and $0.5 \mu \mathrm{mol} / \mathrm{l}$ of Se-Car (about 3.24-fold $v$. control) or $\mathrm{Na}_{2} \mathrm{SeO}_{3}$ (about 3.12-fold $v$. control). These results suggest that concentrations of different forms of Se required for a maximal D1 mRNA level vary in chicken hepatocytes. After resulting in a maximal D1 mRNA level, higher Se supplementation led to a dose-dependent reduction in D1 mRNA levels in all the groups treated with $\mathrm{Se}$, but the degree of reduction in D1 mRNA levels was different between the groups treated with these three forms of Se. As mentioned earlier, the reduction in D1 mRNA levels may be related to excess supplementation and cytotoxicity of Se. At $0.5 \mu \mathrm{mol} / \mathrm{l}$ of added $\mathrm{Se}, \mathrm{Se}-\mathrm{Car}$ and $\mathrm{Na}_{2} \mathrm{SeO}_{3}$ had a relatively greater effect on D1 mRNA than Se-Met $(P<0.05)$, while Se-Met at doses of $1.5-5 \mu \mathrm{mol} / \mathrm{l}$ had a relatively greater effect on D1 mRNA than Se-Car and $\mathrm{Na}_{2} \mathrm{SeO}_{3}$ at equivalent doses $(P<0 \cdot 05)$. These results suggest that regulations of D1 mRNA levels by different forms and concentrations of Se differ in primary cultured chicken hepatocytes.

In summary, these results demonstrate that supplementation of Se in the culture medium can increase GPx activity and D1 mRNA level in primary cultured chicken hepatocytes, while 
excess supplementation of Se causes cytotoxicity and negative effects. The regulations of GPx activity and D1 mRNA by different forms and concentrations of Se vary in chicken hepatocytes. The concentration of Se required for the maximal expression of D1 mRNA in chicken hepatocytes is higher than that of Se required for the maximal expression of GPx4 mRNA.

\section{Acknowledgements}

The final manuscript was read and approved by all the authors, and the authors declare no conflicts of interest. The study was sponsored by the National Natural Science Foundation of China (grant nos 30671547 and 30871892). The contribution of the authors were as follows: X. W. isolated and cultured the chicken hepatocytes, measured the mRNA levels and wrote the paper. C. W. isolated and cultured the chicken hepatocytes, and measured the enzyme activity. C. P. measured the LDH activity. Y. D. measured the protein concentration. $\mathrm{K}$. H. was involved in technical direction, statistical analysis and writing of the paper.

\section{References}

1. The Research Group of Keshan Disease of Chinese Academy of Medical Sciences (1979) Research on the relation between selenium and keshan disease. Acta Acad Med Sin 1, 75-80.

2. Research Team of Environment and Endemic Diseases (1986) Studies on low selenium belt in China and pathogeny of Keshan and Kaschin-beck Diseases. Chin J Environ Sci 7, 89-93.

3. Muth OH, Oldfield JE, Remmert LF, et al. (1958) Effects of selenium and vitamin $\mathrm{E}$ on white muscle disease. Science 128, 1090.

4. Patterson EL, Milstrey R \& Stokstad EL (1957) Effect of selenium in preventing exudative diathesis in chicks. Proc Soc Exp Biol Med 95, 617-620.

5. Brenneisen P, Steinbrenner H \& Sies H (2005) Selenium, oxidative stress, and health aspects. Mol Aspects Med 26, 256-267.

6. Aréchiga CF, Ortíz O \& Hansen PJ (1994) Effect of prepartum injection of vitamin $\mathrm{E}$ and selenium on postpartum reproductive function of dairy cattle. Theriogenology 41, 1251-1258.

7. Kaur P \& Bansal MP (2005) Effect of selenium-induced oxidative stress on the cell kinetics in testis and reproductive ability of male mice. Nutrition 21, 351-357.

8. McKenzie RC, Rafferty TS \& Beckett GJ (1998) Selenium: an essential element for immune function. Immunol Today 19, 342-345.

9. Arthur JR, McKenzie RC \& Beckett GJ (2003) Selenium in the immune system. J Nutr 133, Suppl. 1, S1457-S1459.

10. Qin S, Gao J \& Huang K (2007) Effects of different selenium sources on tissue selenium concentrations, blood GSH-Px activities and plasma interleukin levels in finishing lambs. Biol Trace Elem Res 116, 91-102.

11. Choct M, Naylor AJ \& Reinke N (2004) Selenium supplementation affects broiler growth performance, meat yield and feather coverage. Br Poult Sci 45, 677-683.

12. Schrauzer GN (2000) Anticarcinogenic effects of selenium. Cell Mol Life Sci 57, 1864-1873.

13. Whanger PD (2004) Selenium and its relationship to cancer: an update. Br J Nutr 91, 11-28.

14. Combs GF Jr (2005) Current evidence and research needs to support a health claim for selenium and cancer prevention. J Nutr 135, 343-347.
15. Stadtman TC (1996) Selenocysteine. Annu Rev Biochem 65, $83-100$.

16. Lescure A, Fagegaltier D, Carbon P, et al. (2002) Protein factors mediating selenoprotein synthesis. Curr Protein Pept Sci 3, 143-151.

17. Driscoll DM \& Copeland PR (2003) Mechanism and regulation of selenoprotein synthesis. Annu Rev Nutr 23, 17-40.

18. Baker RD, Baker SS, LaRosa K, et al. (1993) Selenium regulation of glutathione peroxidase in human hepatoma cell line Hep3B. Arch Biochem Biophys 304, 53-57.

19. Weiss Sachdev S \& Sunde RA (2001) Selenium regulation of transcript abundance and translational efficiency of glutathione peroxidase-1 and -4 in rat liver. Biochem J 357, 851-858.

20. Drevet JR (2006) The antioxidant glutathione peroxidase family and spermatozoa: a complex story. Mol Cell Endocrinol 250, $70-79$.

21. Kong BW, Kim H \& Foster DN (2003) Cloning and expression analysis of chicken phospholipid-hydroperoxide glutathione peroxidase. Anim Biotechnol 14, 19-29.

22. Arthur JR (2000) The glutathione peroxidases. Cell Mol Life Sci 57, $1825-1835$.

23. Miyazaki S \& Motoi Y (1992) Tissue distribution of monomeric glutathione peroxidase in broiler chicks. Res Vet Sci 53, 47-51.

24. Köhrle J (2000) The deiodinase family: selenoenzymes regulating thyroid hormone availability and action. Cell Mol Life Sci 57, 1853-1863.

25. Bermano G, Nicol F, Dyer JA, et al. (1995) Tissue-specific regulation of selenoenzyme gene expression during selenium deficiency in rats. Biochem $J$ 311, 425-430.

26. Chang WP, Combs GF Jr, Scanes CG, et al. (2005) The effects of dietary vitamin $\mathrm{E}$ and selenium deficiencies on plasma thyroid and thymic hormone concentrations in the chicken. Dev Comp Immunol 29, 265-273.

27. Zuberbuehler CA, Messikommer RE, Arnold MM, et al. (2006) Effects of selenium depletion and selenium repletion by choice feeding on selenium status of young and old laying hens. Physiol Behav 87, 430-440.

28. Root EJ \& Combs GF Jr (1988) Disruption of endoplasmic reticulum is the primary ultrastructural lesion of the pancreas in the selenium-deficient chick. Proc Soc Exp Biol Med 187, 513-521.

29. Fischer J, Bosse A, Most E, et al. (2008) Selenium requirement of growing male turkeys. Br Poult Sci 49, 583-591.

30. Rayman MP (2004) The use of high-selenium yeast to raise selenium status: how does it measure up. Br J Nutr 92, 557-573.

31. Yoon I, Werner TM \& Butler JM (2007) Effect of source and concentration of selenium on growth performance and selenium retention in broiler chickens. Poult Sci 86, 727-730.

32. Leeson S, Namkung H, Caston L, et al. (2008) Comparison of selenium levels and sources and dietary fat quality in diets for broiler breeders and layer hens. Poult Sci 87, 2605-2612.

33. Fujii M, Yoshino I, Suzuki M, et al. (1996) Primary culture of chicken hepatocytes in serum-free medium ( $\mathrm{pH}$ 7.8) secreted albumin and transferrin for a long period in free gas exchange with atmosphere. Int J Biochem Cell Biol 28, 1381-1391.

34. Wu X, Huang K, Wei C, et al. (2010) Regulation of cellular glutathione peroxidase by different forms and concentrations of selenium in primary cultured bovine hepatocytes. $J$ Nutr Biochem 21, 153-161.

35. Dringen R, Kussmaul L \& Hamprecht B (1998) Detoxification of exogenous hydrogen peroxide and organic hydroperoxides by cultured astroglial cells assessed by microtiter plate assay. Brain Res Protoc 2, 223-228.

36. Lei XG, Evenson JK, Thompson KM, et al. (1995) Glutathione peroxidase and phospholipid hydroperoxide glutathione peroxidase are differentially regulated in rats by dietary selenium. J Nutr 125, 1438-1446. 
37. B'Hymer C \& Caruso JA (2006) Selenium speciation analysis using inductively coupled plasma-mass spectrometry. J Chromatogr A 1114, 1-20.

38. Zeng H \& Combs GF Jr (2008) Selenium as an anticancer nutrient: roles in cell proliferation and tumor cell invasion. $J$ Nutr Biochem 19, 1-7.

39. Payne RL \& Southern LL (2005) Comparison of inorganic and organic selenium sources for broilers. Poult Sci 84, 898-902.

40. Kim YY \& Mahan DC (2001) Comparative effects of high dietary levels of organic and inorganic selenium on selenium toxicity of growing-finishing pigs. J Anim Sci 79, 942-948.

41. Pan C, Huang K, Zhao Y, et al. (2007) Effect of selenium source and level in hen's diet on tissue selenium deposition and egg selenium concentrations. J Agric Food Chem 55, 1027-1032.

42. Mihajlović M (1992) Selenium toxicity in domestic animals (article in Serbian). Glas Srp Akad Nauka Med 131-144.

43. Tiwary AK, Stegelmeier BL, Panter KE, et al. (2006) Comparative toxicosis of sodium selenite and selenomethionine in lambs. $J$ Vet Diagn Invest 18, 61-70.

44. Bell RR, Nonavinakere VK, Soliman MR, et al. (1991) Effect of in vitro treatment of rat hepatocytes with selenium, and/or cadmium on cell viability, glucose output, and cellular glutathione. Toxicology 69, 111-119.

45. Müller AS \& Pallauf J (2003) Effect of increasing selenite concentrations, vitamin E supplementation and different fetal calf serum content on GPx1 activity in primary cultured rabbit hepatocytes. J Trace Elem Med Biol 17, 183-192.

46. Lei XG, Dann HM, Ross DA, et al. (1998) Dietary selenium supplementation is required to support full expression of three selenium-dependent glutathione peroxidases in various tissues of weanling pigs. $J$ Nutr 128, 130-135.

47. Salman M, Muğlali OH \& Selçuk Z (2009) Investigations into effects on performance and glutathione peroxidase activity in broilers when increasing selenium contents of complete diets appropriate to animals' selenium requirements by adding different selenium compounds (organic v. inorganic). Dtsch Tierarztl Wochenschr 116, 233-237.

48. Spyrou G, Björnstedt M, Skog S, et al. (1996) Selenite and selenate inhibit human lymphocyte growth via different mechanisms. Cancer Res 56, 4407-4412.

49. Garberg P, Ståhl A, Warholm M, et al. (1988) Studies of the role of DNA fragmentation in selenium toxicity. Biochem Pharmacol 37, 3401-3406.

50. Uezono Y, Toyohira Y, Yanagihara N, et al. (2006) Inhibition by selenium compounds of catecholamine secretion due to inhibition of $\mathrm{Ca}^{2+}$ influx in cultured bovine adrenal chromaffin cells. J Pharmacol Sci 101, 223-229.

51. Ebert R, Ulmer M, Zeck S, et al. (2006) Selenium supplementation restores the antioxidative capacity and prevents cell damage in bone marrow stromal cells in vitro. Stem Cells $\mathbf{2 4}$, $1226-1235$.

52. Keck AS \& Finley JW (2006) Aqueous extracts of seleniumfertilized broccoli increase selenoprotein activity and inhibit DNA single-strand breaks, but decrease the activity of quinone reductase in Hepa 1c1c7 cells. Food Chem Toxicol 44, 695-703.

53. Sneddon AA, Wu HC, Farquharson A, et al. (2003) Regulation of selenoprotein GPx4 expression and activity in human endothelial cells by fatty acids, cytokines and antioxidants. Atherosclerosis 171, 57-65.

54. Romanowska M, Kikawa KD, Fields JR, et al. (2007) Effects of selenium supplementation on expression of glutathione peroxidase isoforms in cultured human lung adenocarcinoma cell lines. Lung Cancer 55, 35-42.

55. Sunde RA, Evenson JK, Thompson KM, et al. (2005) Dietary selenium requirements based on glutathione peroxidase-1 activity and mRNA levels and other Se-dependent parameters are not increased by pregnancy and lactation in rats. $J$ Nutr 135, 2144-2150.

56. Christensen MJ, Cammack PM \& Wray CD (1995) Tissue specificity of selenoprotein gene expression in rats. $J$ Nutr Biochem 6, 367-372. 